\title{
Analyzing Iago's Speech in Shakespeare's Othello
}

\author{
Nimer Abuzahra \\ Hebron University, Palestine \\ e-mail:nabuzahran@gmail.com \\ Rami Salahat \\ Hebron University, Palestine \\ e-mail:abu-ali.2009@gmail.com
}

\begin{abstract}
:
This paper aims to reveal and analyze Iago's speech in Shakespeare's Othello. Iago's use of animal metaphors in Othello is analyzed through Conceptual Metaphor Theory (CMT). Moreover, Iago's words in the play are connected to race, gender and identity and analyzed through Critical Discourse Analysis (CDA). Finally, Iago's rhetorical discourse is analyzed through Rhetorical Theory to examine his use of rhetorical devices such as rhetorical questions. The findings of this study show that Iago's use of animal metaphors in the play is to dehumanize and degrade other characters. Further, Iago is able to alienate Othello because of his different identity and different color from the Venetian society. What's more, Iago has shown misogynistic attitudes toward women through the course of the play. In addition, Iago shows an exceptional ability in his rhetoric. He manipulates most of the characters in the play and was able to deceive all of them. It can be concluded, then, that Iago's use of animal metaphors is conceptualized and connected to his cognitive mind. Moreover, Iago's racist language in the play reflects the racist attitudes toward 'non-white' people in Shakespeare's time. Finally, Iago uses different rhetorical techniques such as rhetorical questions to manipulate other characters which shows how language can be exploited to achieve negative impact on others.
\end{abstract}

Keywords: Othello, Iago, Speech, Moor, Venice. 


\section{Introduction}

Othello, The Moor of Venice was written between 1601-04 (Hadfield, 2005; Sanders, 2003). It is written in the period when Shakespeare reached his peak of fame. Othello is a black Moor who lives in Venice and occupies a good military and social status. He is married to Desdemona and then suffers from alienation and racism imposed on him by other characters like Iago, Rodrigo, Brabantio and Emilia which leads to his downfall at the end of the play.

Unlike other Shakespearean plays, Othello starts with no mentioning of the hero. Adelman (1997) points out that "before we meet Othello, we are utterly dependent on Iago's and Rodrigo's descriptions of him" (p.125). The first scene of the play is replete with racial pejorative descriptions of Othello. This suggests that the playwright is preparing his readers for the entrance of something not human (Rose, 2008). In other words, Othello is portrayed with animal images from the very beginning of the play which aims to dehumanize him and make him look like animals. If Rand (1950) is right when claiming that Shakespeare's introductory scenes are always keynotes, then Shakespeare invokes his readers' anxieties and heightens their fears about what they already know about Moors or black people.

On the other hand, there are critics who believed that the play is racially motivated. However, they think that it is inappropriate to consider that Shakespeare is a racist or suffered from race prejudice. Baecker (1999) believes that Shakespeare's willingness to explore issues of racial differences would be recognized by exposing the play between Moors and European. In contrast, Reitz-Wilson (2004) points out that Shakespeare was well aware of racial tension in England and included this tension in the play. Moreover, Ogued thinks that the playwright "has shared some of the deep-seated fears of his contemporaries about black people ... and that Othello expresses as well as confirms the prejudice behind Elizabeth's decree banishing Negros from England in 1601" (as cited in Reitz-Wilson, 2004, p. 2).

In sum, Neill (1998) flatly remarks that the play is a "foundational text in the emergence of modern European racial conscious" (p.361) and it is like "the culture that produced it" (Vitkus, 1997, p.145). For those who don't like Shakespeare to be a racist because of his statues, the play represents for them a resistance of racism against black people. However, as Neill (1989) has established among others, there is a sense of racial scandal can be seen through critics' comments on the play like Rymer and Coleridge who asserted that Othello was never intended to be a hero.

\subsection{The Source of the play}

There is a general consensus among critics that the original source of Othello is Cinthio's novella Hecatommithi. The deviations of Shakespeare from his original source of the play, as critics have established, are remarkable, significant and revealing. To start with, Shakespeare transformed Cinthio's Moor _ a baptized Saracen of North coast of Africa into a 'Negro' [with 'thick lips' and 'sooty bosom'] (Braxton, 1990, p. 1). This suggests that the playwright intended his hero to be a Negro despite the fact that Negros and Moors were considered the same in the Elizabethan era. 
It is important to state that Shakespeare has invented the names of his characters unlike Cinthio's source. He invented Othello's name which, according to Egan (2007), and Bate (2010), if pronounced "with hard 't' as though it were 'Otello' made him sound like an Ottoman" (p.110). What's more, Iago's name changed from the 'ensign' in Cinthio's novella to Iago in Shakespeare which is a Spanish name of a saint who is a well-known slayer of the Moors (Konigsberg, 2012). Indeed, the choice of Shakespeare's characters' names isn't a matter of random choice.

Ironically enough, Shakespeare scrapped the fact that it is the ensign, Shakespeare's Iago, who kills Desdemona in Cinthio and instead he made Othello the killer. The scene in which a white woman being smothered by a black man confirms the deep fears of the interracial marriage. Roux (2009) reports that in Baltimore, a soldier shot at the actor playing Othello in an 1822 production of the play and broke his arm posting that it "would never be said in my presence a confounded Negro has killed a white woman" (p.23). It can be deduced that Shakespeare's altering of the main source and the remodeling of the characters aim at increasing the readers' fears and emphasizes the stereotypes of Moors and black people.

\subsection{The Conceptual Metaphor Theory(CMT)}

Conceptual Metaphor Theory was developed by Lakoff and Johnson in the 1980s. They believe that the literary language seems to be exclusive for the use of metaphors. Instead, they suggest that metaphors are used in the bulk of everyday language and aren't restricted to the use of poems or plays or any other literary genres.

Traditionally, metaphors have been treated as part of poetic imagination and extraordinary language (Lakoff \& Johnson, 1980). What Lakoff and Johnson introduce considers the concepts in which people live by. To put it simply, they argue that people have concepts in their minds when they use language and all these concepts are metaphorical. Lakkof (1993) rejects the traditional definition of metaphor which states that metaphor is a novel or poetic "linguistic expression where one or more words for a concept are used outside of their normal conventional meaning to express a similar convention" (p. 202). Rather, Lakoff claims that poetic metaphor expressions aren't in language but in thought and that they are general mappings across conceptual domains and these general principles which take the form of conceptual mappings apply not only to poetic language but also to much of ordinary everyday language.

As a matter of fact, metaphors, for Conceptual Metaphor theorists, are common in everyday language and they are important for communicating about abstract concepts like time and emotions (Bowdle and Gentner, 2005). The traditional approach to metaphors treats metaphors as comparisons that highlight preexisting similarities between the target and the concepts. In other words, the standard approach to metaphors interprets metaphors through the similarities between a thing or a person compared to another thing which doesn't belong to the former category and analyze the connotations that this comparison reveals. 


\subsection{Animal Metaphor}

Animal Metaphors (AM) can be categorized under the concept: 'Man Is Animal' according to Lakoff and Johnson theory. That is, there is a source domain and a target domain when someone is described with animalistic traits. For example, if someone says: He is a lion, this means that 'he' is the target domain and 'lion' is the source domain. Moreover, this sentence implies that the described person shares some characteristics with the 'lion' like bravery. To take another example, someone can be described as a 'fox'. This means that he is cunning or clever like a fox. However, some of the animal metaphors can be positive or negative depending on the culture which produces them.

\subsection{Critical Discourse Analysis}

Critical Discourse Analysis is considered to be one of the main critical tools toward language in use and its connection with culture and society. The main purpose of CDA is to analyze "opaque as well as transparent structural relationships of dominance, discrimination, power and control as manifested in language" (Blommaret, 2005, pp. 24-25).

Critical Discourse Analysis (CDA) is "a type of discourse analytical research that primarily studies the way social power abuse, dominance, and inequality are enacted, reproduced, and resisted by text and talk in the social and political context" (Van Dijk, 2011, p. 352). Wodak and Meyer (2009) assert that one of popular definitions of CDA is that discourse and language use in speech and writing are seen as a form of social practice. That is, discourse is socially constitutive as well as socially conditioned. Moreover, CDA sees language as social practice and considers the context of language use to be crucial.

Additionally, Fairclough (2012) remarks that CDA doesn't only describe existing realities about social issues and language, but also evaluates them and seeks to explain them. Wodak and Fairclough (2004) point out that the term 'critical' may imply negative meanings. However, 'critical' for CDA means "the use of rational thinking to question arguments of prevailing ideas, that is, more generally applying not to take anything for granted and challenging surface meanings" (Wodak and Fairclough, 2004, p. 40). Add to this, Fairclough stresses the fact that no discourse or social activity is ideology-free. As a result, CDA is valid to unravel ideologies which underpin texts and talks.

\section{Methodology: The design of the research}

This study is a descriptive qualitative one, for it will describe and critically analyze the speech of Iago in Othello. Various theories will be applied to study and analyze Iago's speech in the play. First of all, the Conceptual Metaphor Theory (CMT) will be applied to study the animal metaphors in Iago's speech. Under the metaphorical conceptualization MAN IS ANIMAL or MAN BEHAVIOR IS LIKE ANIMAL BEHAVIOUR Iago's use of animal metaphors in Othello can be categorized and linked cognitively to Iago's mind and how he thinks of other characters, like Othello, 
Desdemona, Cassio, in animalistic terms and how he describes their actions in comparison to animal behaviors.

Moreover, several theories of Critical Discourse Analysis (CDA) will be applied to reveal the social and verbal interactions between Iago and other characters in Othello and to unravel Iago's view of race, gender and identity as social issues. Finally, the Rhetorical Analysis Theory will be applied as well to unearth the use of rhetorical devices and techniques in Iago's speech and how Iago's linguistic skills enable him to achieve his goals through the use of rhetoric.

\section{Animal metaphors in Iago's speech}

There are two procedures adopted to analyze Iago's use of animal metaphor. First, animal metaphors are analyzed linguistically. To achieve this, several dictionaries and thesauruses were consulted. Moreover, dictionaries provide data about animal metaphors and their occurrences in different cultures which will be useful for the metaphors interpretation. The second procedure is a cognitive analysis of Iago's use of animal metaphor. This analysis is inspired from the Conceptual Metaphor Theory (CMT) and aims at finding out whether these animal metaphors are conceptualized in people's mind or not.

In Act One, Scene One, Iago asks Rodrigo to awaken Brabantio to tell him that Othello has married Desdemona secretly, he tells Brabantio that "an old black ram is tupping your white ewe" (1.1.89-90). Interestingly, the word 'ram' is defined in the Thesaurus of Traditional English Metaphors as a metaphor used to express an oversexed man or a lecher. Ironically enough, black people, as Othello, are known as lascivious and lustful people. Rodrigo, as well, describes Othello as "a lascivious Moor" (1.1.125). Vitkus (1997) remarks that there are "alleged sexual excesses linked to Muslims, Moors and black African" (p. 159). Iago's bestial images of interracial love-making between Othello and Desdemona enkindles Brabantio's wrath against them.

As for Desdemona, Iago describes her as a "white ewe". Ewes or the female sheep are used metaphorically to describe beautiful women in a gang of thieves. The meaning that Iago wants to convey to Brabantio is that his daughter, Desdemona, has fallen in the hands of lascivious thieves and he means Othello with no doubt. This is confirmed by Iago when he says "Awake ho, Brabantio! Thieves, thieves! Look to your house, your daughter, and your bags! Thieves, thieves" (1.1.79-82). The word 'thief' here is repeated four times to stress the idea that Othello has stolen Desdemona. It is quite clear that these two animal metaphors are conceptualized. In other words, people understand 'rams' as lascivious animals and they use them to describe people who have these attributes. Moreover, women are described as 'ewes' as they might be easily deceived or 'stolen' by men.

Iago continues his use of animal metaphors when he describes Othello as a 'Barbary horse'. He tells Brabantio that "your daughter will be covered with a Barbary horse" (1.1.111). Barbary horses are defined in the English Dictionary as "a northern African breed with great hardiness and stamina". Iago chooses this type of horses to mean Othello, that he is a barbaric from north Africa. Despite the fact the Barbary 
horses are known for their capacity of endurance and hardiness which are positive traits, Iago uses this animal metaphor negatively and racially to describe Othello.

In addition, Iago tells Brabantio that if he doesn't prevent the marriage of Othello and Desdemona, he will have "coursers for cousins, and jennets for germans" (1.1.113). Jennets are defined in Oxford English Dictionary (OED) as "a kind of small Spanish horse". Iago here uses 'jennets' as small horses to tell Brabantio that his grandsons will be jennets like their father, Othello, the Barbary horse. It is clear that Iago here is trying to heighten the anxieties of Brabantio about miscegenation. In other words, Iago suggests that Othello is a beast and his sons from Desdemona will be beasts like him. Related to this, Hadfield (2003) points out that the love or marriage of a white woman to a black man is considered to be one of the central taboos of the Elizabethan time because of the attendant fears of mixed-race children.

On the other hand, Rodrigo wants to drown himself because the Senate approves Othello's marriage of Desdemona. His love to Desdemona now has no value as she married Othello so he wants to die because he lost her. However, Iago mocks Rodrigo's weakness and says "Ere I would say I would drown myself for the love of a guinea-hen, I would change my humanity with a baboon" (1.3.309-10). In fact, Iago uses the animal metaphor 'guinea-hen' to refer to Desdemona. A guinea-hen, according to Oxford English Dictionary (OED), is a fowl hen especially a female one. Iago is blaming Rodrigo because he wants to drown himself for a 'fowl' woman who doesn't deserve to die for. The purpose of this use of animal metaphor is to dehumanize Desdemona comparing her to a fowl hen. As a matter of fact, women are often described as 'hens' or 'chickens'. Silaski (2014) observes that guinea-hen is being applied to a woman characterized by naiveté and being easily deceived. Regarding the use of a 'baboon' by Iago as an animal metaphor, Iago is describing Othello as a baboon. Oxford English Dictionary defines a baboon as "a large Old World ground-dwelling monkey with a long doglike snout and large teeth". Ironically enough, a 'baboon' means also an ugly or uncouth person. It is quite clear here that Iago is portraying Othello as an ugly person comparing him to baboons. Through the course of the play, Othello is being constantly described with traits that portray him as ugly. Brabantio, for example, is shocked that how his daughter loves "such a thing as thou-to fear not to delight" (1.2.71). Iago, describing Othello as a baboon, is blaming Rodrigo for his intention to drown himself as if he is saying that Rodrigo is false because he wants to lose his humanity because of a 'baboon'.

The last animal metaphor Iago uses in Act one is when he describes Othello as an 'ass' in a very racist way. He says "And will as tenderly be led by the nose as asses are" (1.3.384). Actually, 'asses' have more than one meaning or used to convey several images. First, 'asses' are used metaphorically to mean "an obstinate fool". Moreover, asses or donkeys are known for their stupidity and stubbornness. Furthermore, asses are known for their ability to do hard works. Iago is downgrading Othello to the state of animals in a racist way. 


\subsection{Act Two, Scenes One and Three}

In Act two, scene one, Iago expresses his cynical view of women in a conversation with Desdemona. He says "Come on, come on; you are pictures out of doors, bells in your parlours, wild-cats in your kitchens" (2.1.108-109). Wild cats are used metaphorically, according to the Thesaurus of Traditional English Metaphors, to mean "a woman of fierce temper". Moreover, Sanders (2003) points out that Iago's statement is a proverb which means that women are in church saints, abroad angels, and at home devils. This suggests that Iago has a bad view of women in general, that they don't seem what they really are. Furthermore, wild cats are known for their ferocity which means that they can be harmful. The term 'wild' suggests also that such cats aren't domestic, that is, they don't live with people. It is clear, then, that Iago's use of this animal metaphor to describe women is that it is hard to live with them without being subjected to their ferocity and wildness.

Furthermore, Iago describes Cassio as a fly. He says "With as little a web as this will I ensnare as great a fly as Cassio" (2.1.164). A 'fly' is known as worthless creature. As a result, Iago is saying that Cassio seems to be big, but in fact he is as small as a fly. This description aims to downgrade Cassio describing him as worthless as a fly.

Additionally, Iago describes Othello for the second time in this Act as an 'ass'. He says "Make the Moor thank me, love me, and reward me, for making him egregiously an ass" (2.1.289-290). The purpose of repeating this animal metaphor by Iago is to dehumanize Othello reducing him to an animal level. Sharma (2015) points out that the repetition of Iago's use of animal metaphors is an evidence of his debased mentality. However, Gonzalez (1985, p. 45) confirms that "Iago's ordered use of animal imagery works best to stir the emotions of his victims, thereby making rational thought as difficult for them as it is for an animal".

In Act two, scene three, Iago is urging Cassio to drink in order to become a drunk and lose his balance so he would do things he doesn't usually do. In his aside, Iago says "He'll be as full of quarrel and offence as my young mistress' dog" (2.3.43). According to most of the consulted dictionaries like Oxford English Dictionary, dogs are domesticated animals kept by people for guarding. However, Iago's description of Cassio as a 'mistress dog' means that Cassio is preferred by women or he is a playful. As a matter of fact, Iago expresses this image of Cassio when he says "He [Othello] hath a person [Cassio] and a smooth dispose to be suspected, framed to make women false" (1.3.379-380). Moreover, Iago is degrading Cassio by describing him as close to women through this animal metaphor. Through the course of the play, Iago's view of Cassio is that he is a playful man. He describes him as "damned in a fair wife" (1.1.21). In addition, Iago is jealous of Cassio because the latter "hath a daily beauty in his life" (5.1.19). In conclusion, Iago is downgrading Cassio by saying that he is close to women and has no experience in the battlefields.

\subsection{Act Three, Scene Three}

In this Act, Iago repeats the same strategy he used with Brabantio to increase his anger towards Othello. He tells Brabantio that "an old black ram is tupping your white ewe" (1.1.89-90). The same strategy is exploited by Iago to incite Othello 
against Desdemona and Cassio by describing the alleged sexual relationship between them. Both strategies used by Iago depend on the use of animal metaphors. For example, Iago says that Desdemona and Cassio in their sexual intercourse "Were as prime as goats, as hot as monkeys, as salt as wolves in pride" (3.3.404405). Goats, according to the Thesaurus of traditional English Metaphors, are used metaphorically to mean a "licentious, foolishly obstinate man and they are regarded as lascivious animals". Moreover, Sanders (2003) points out that the phrase 'as prime as goats' was first used by Shakespeare in a sense which means lecherous. In addition, the animal metaphor 'as hot as monkeys' is used by Iago to show how Desdemona and Cassio are sexually excited. Related to this, Iago's animal metaphor 'as salt as wolves' also means lust. Wolves, according to (OED) are used figuratively "to refer to a rapacious, ferocious or voracious person". This implies that Desdemona and Cassio in their relationship were rapacious and voracious. Likewise, the terms 'prime', 'hot', and 'salt' are used by Iago to refer to sexual excitement. The use of different animals to describe this sexual relationship is to make things worse and uglier in Othello's mind.

\subsection{Cognitive Analysis of Animal Metaphors in Iago's Speech}

Iago describes Othello as a 'black ram'. In cognitive terms or according to Conceptual Metaphor Theory (CMT) procedures, there is a source domain and a target domain in this metaphor. The source domain is 'Othello' while the target domain is the 'ram'. Moreover, there is a conceptual mapping from the source domain to the target domain. To make it more clear, Othello is seen as a lustful and lascivious person since he is black. As a result, he is compared to an animal, a ram, which has these traits. Rams are known as lascivious animals, so to describe Othello's lustful character he is compared to a lustful animal. In fact, white people can be lustful as well but Iago is specific in his use of this metaphor so he said a 'black ram' to make it clear that Desdemona is married to a black person. The second part of this metaphor is when Iago says 'a black ram is tupping your white ewe'. Desdemona here is described as a ewe. As mentioned before, a 'ewe' is a beautiful woman in gang of thieves. The conceptual mapping here is that Desdemona is being stolen as ewes can be stolen without resistance or without knowing that they are stolen or deceived because of their foolishness. As a result, the conceptual mapping of this metaphor can be classified as follows:

Lustful, Lascivious:

- Man is a ram, lustful as a ram, black people are lascivious

Foolishness

- Women are ewes, women can be easily deceived,

In addition, Iago describes Othello as a 'Barbary horse' and his children from Desdemona will be 'jennets'. The conceptual mapping of this metaphor is that black people are barbaric as well as their children. The common knowledge of Barbary horses is that they are stubborn and strong. Moreover, they are known for their hardiness and stamina. 
Moreover, Desdemona is described by Iago as a 'guinea-hen'. In fact, 'guinea-hen' is used metaphorically to refer to women or precisely a fowl woman. Iago uses this metaphor when he was trying to convince Rodrigo not to drown himself for the love of a 'fowl' woman. Hens or chickens are known for their foolishness, so to describe Desdemona's behavior of marrying Othello, she was compared to a 'guinea-hen' and her choice is described by Iago as a foolish one.

Additionally, Iago also describes Othello as a 'baboon' and as an 'ass'. In fact, baboons are ugly so Iago here is describing the physical appearance of Othello as ugly. He expresses this when he tells Rodrigo "what delight shall she have to look on the devil?" (2.1.216). Moreover, he describes Othello as an 'ass'. As mentioned before, asses are known for their stupidity and foolishness and for their endurance.

It should be known that most of Iago's metaphors which are used to describe Othello seem to be racist, which support the idea that Othello is racially motivated.

Not only Iago was racist against Othello, but he also has a cynical view of women. He describes women as 'wild cats'. The common knowledge of wild cats is that they aren't domestic and they have fierce tempers. Fontecha and Catalan (2003) assert that "when we say that a woman is [a cat or wild cats], we mean that she is a shrewish, ill tempered and furious" (p. 781).

Furthermore, Iago describes Cassio as a 'mistress dog'. Iago means by using this description is that Cassio is a playful and doesn't deserve his place as a lieutenant for Othello. The traits of the source domain, Cassio, is being mapped onto the target domain, a mistress dog, in order to understand the personality of Cassio.

In conclusion, all of Iago's animal metaphors in Othello are used to highlight, in Iago's perceptions of things, the negative traits of people. For him, he thinks that black people are lascivious, ugly, barbaric, stubborn, and foolish. To best describe that, Iago mapped these features onto animals which are known to have such traits. Rams, Barbary horses, baboons, and asses are animals which have these features so they are used to understand or describe black people behaviors. It is worth mentioning here that Iago's animal metaphors used to describe Othello are of two kinds. First, Iago uses animal metaphors to describe Othello's physical appearance like baboons. Second, Iago uses animal metaphors to portray Othello's characteristics like rams to express lust, and asses to express foolishness. In return, Iago believes that women are foolish, stupid, ill or fierce tempered and can be easily deceived. He expresses these so called features by comparing them to animals like ewes, guinea-hen, cats and wild cats as the common knowledge about these animals show that they have such traits. The choice of these animals by Iago isn't random. In other words, in people's cognitive minds, these animals have traits which Iago uses to describe the characters' behaviors.

\section{The Discourse of Racism in Iago's Speech}

Iago is considered as one of the most racist characters in Othello. His hate to black people appears clearly through his interactions with other characters and in his soliloquies. Racism is to differentiate between people according to their color. Iago 
uses Othello's color to achieve his goals by stressing the dangers of black people on white communities. In fact, Iago describes Othello with common traits known for the white people about black people. In this regard, Iago shares his attitudes about black people with his community, but he highlights their danger on the Western society more than others.

The first Act of Othello is replete with racist attitudes from Iago towards Othello. He awakens Brabantio, Desdemona's father, to tell him that Othello has married his daughter. In fact, Iago didn't tell Brabantio that his daughter had married secretly. Instead he says "Awake! What ho, Brabantio! Thieves, thieves! Look to your house, your daughter, and your bags! Thieves, thieves" (1.1.80-82). Iago's words are suggestive rather than overt that Othello is a thief and has stolen Desdemona. Moreover, the word 'thief' suggests that something has been taken illegally or clandestinely which means that Othello's marriage of Desdemona isn't approved or legal. Iago continues his strategy to incite Brabantio. He says:

Zounds, sir, you're robbed; for shame, put on your gown;

Your heart is burst; you have lost half your soul;

Even now, now, very now, an old black ram

Is tupping your white ewe. Arise, arise;......

Or else the devil will make a grandsire of you.

$$
(1.1 .87-91)
$$

In these lines, Iago is stressing the idea that Desdemona has been stolen. He didn't refer to Othello by name but rather he describes him as an 'old black ram' and as a 'devil'. It was common in Britain to refer to black people as lascivious and devils. The word 'ram' connotes lust, that is Othello is a lascivious ram who beguiled Desdemona and stole her.

Brabantio still didn't get the message that Iago wants to convey. As a result, Iago continues his incitement:

You'll have your daughter covered with a Barbary

Horse, you'll have your nephews neigh to you, you'll have

Coursers for cousins, and jennets for germans. (1.1.111-113)

It is clear that Iago stresses the idea that Desdemona has been taken by a devil. Hadfield $(2005$, p. 2) points out that "English writers often assumed, explicitly or implicitly, that God had made them in his own image". This suggests that black people are inferior and associated with devils. Moreover, Iago plays on the idea of miscegenation since it was one of the taboos in the Western society to see a black man married to a white women. Hadfield (2005) also asserts that Western people stressed the purity of blood and the need to preserve their race.

In Act One, Scene three, Iago has extended speeches to convince Rodrigo not to drown himself. He counts the reasons why Rodrigo should be patient in order to achieve their goals represented in spoiling Othello's marriage. Iago tells Rodrigo that Desdemona "must change for youth; when she is sated with his body she will find the error of her choice" (1.3.339-340). This racist language aims to show that the 
marriage of Desdemona and Othello isn't natural. That is black and white can never meet together and if that happened this will be changed immediately. It seems that Iago tries to convince Rodrigo that it is necessary to stop this marriage and break the bond between Othello and Desdemona regardless of the consequences.

At the end of the play, Iago was unmasked in front of other characters in the play. Surprisingly, Iago who never stops talking through the play, refuses to give any explanations for what he had done. His last words are "Demand me nothing; what you know, you know. From this time forth I never will speak word" (5.2.300-301). Neill (1989) aptly remarks that Iago's lines means that what he did was because of racial anxieties. This suggests that Iago was motivated with racist attitudes when he planned to destroy Othello. There is plain evidence that Iago is a racist and as a result his refusal to talk is as if he is saying implicitly that he had done what he did because of his hate to black people.

\section{The Discourse of Gender in Iago's Speech}

Gender, according to Fontecha and Catalan (2003, p. 772), is defined as "a set of socially acquired attributes and patterns of behavior allotted to each of the members of the biological category of male and females". This suggests that there is a hierarchy in a society in which males have higher rank than females. Moreover, this also hints to a discrimination between sexual categories. Most importantly, this discrimination between men and women takes place in language use. To put it simply, in a society governed by men, the attributes of control in a masculine society are reflected in the language use. Females, as a result, are usually described with linguistic terms which show humiliation and derogation.

Iago's speech in Othello has considerable statements of humiliation to women. $\mathrm{He}$ compares them and describes them with animalistic language. Moreover, Iago has a cynical view of women that he deals with them as if they were in a lower rank than men. Further, Iago has the idea of generalization about women. That is, if a woman is bad then all women are bad. Through the play, Iago describes the three women characters, Desdemona, Emilia and Bianca, with words like 'whores' and 'strumpets'. This negative portrayal of women led to the death of Emilia and Desdemona at the end of the play.

Iago reveals his cynical view of women in his conversation with Desdemona and Emilia, his wife. When Cassio kisses Emilia, Iago says "Sir, would she give you so much of her lips as for her tongue she oft bestows on me you would have enough" (2.1.100-03). This suggests that Emilia seems to be polite and courteous but at home she is nervous and talkative. This is confirmed when Iago continues his description of Emilia:

I find it still when I have list to sleep

Marry, before your ladyship, I grant

She puts her tongue a little in her heart

And chides with thinking (2.1.105-108). 
It is clear that Iago is complaining about Emilia's behaviors with him and how she talks a lot about him negatively. However, Iago, then, turns to start talking about women in general:

Come on, come on; you are pictures out of doors, bells in your parlours, wild-cats in your kitchens, saints in your injuries,

devils being offended, players in your housewifery, and no housewives in your beds. (2.1.108-111).

In these lines, Iago portrays women in a very bad view. First, he thinks that women don't seem what people think of them. That is, if they were saints and courteous outside their homes, they turned to be 'wild cats' and 'players' in their houses. In fact, this negative view of women proves that Iago is a misogyny. That he hates women accusing them all to be playful and double-faced. Iago uses the pronoun 'you' to generalize his view of women and he isn't specific of who that 'you' is. These misogynistic attitudes of Iago toward women prove his bad-conscious.

Furthermore, Iago believes that Desdemona's love for Othello isn't real. He confirms to Rodrigo that "she first loved the Moor but for bragging and telling her fantastical lies" (2.1.213-214). It is true that Desdemona doesn't love Othello for his physical appearance, but Iago's view of women's love for their husbands is generalized. In other words, any woman, according to Iago, loves her husband for materialistic reasons and not for real love. This is confirmed by Iago when he ascertains Rodrigo that "the wine she drinks is made of grapes" (2.1.238). This suggests that women aren't different from each other and they look all the same. That is if a woman was bad, then all women are bad.

In Act three, Iago convinces Othello of Desdemona's alleged infidelity. He says that:

I know our country disposition well:

In Venice they do let God see the pranks

They dare not show their husbands. Their best

Conscience. Is not to leave't undone, but keep't unknown. (3.3.203-207).

Iago here introduces himself as a cultural advisor of Othello. Iago's role turned to be prescriptive rather than descriptive. In other words, he confirms Othello that he is an expert in the traits of his country's women so Othello must accept all what he says. He tells Othello that his country's women show their lovers what they don't show their husbands. That is, women in Venice appear to have chastity but in fact they are deceitful. Iago's words have affected Othello who points out that "we can call these delicate creatures ours and not their appetites" (3.3.271-272).

As stated earlier, Iago thinks that all women are dishonest including his wife, Emilia. When the latter steals the handkerchief from Desdemona, Iago says:

Iago: How now? What do you here alone?

Emilia: Do not you chide; I have a thing for you.

Iago: You have a thing for me? It is a common thing -

Emilia: Ha! 
Iago: To have a foolish wife. (3.3.302-306).

In these lines, Iago accuses his wife Emilia that anything she has is a common thing, that is it doesn't belong to himself alone. Moreover, he describes her as foolish which is a general view of Iago towards all women. Moreover, Emilia is aware of how her husband thinks of her. She says "I nothing but to please his fantasy" (3.3.301). This suggests that she obeys Iago and does whatever he wants.

Further, Iago succeeds in making Othello think and behave as he wants him to do. Iago advises Othello that Desdemona's "honor is an essence that's not seen: they have it very oft that have it not" (4.1.16-17). In fact, these lines come after Othello has asked Iago for an 'ocular proof' of his wife's infidelity. Iago here suggests that women's honor is something unseen so they can give it to anyone without being caught or observed. One can conclude here that Iago's view of women is very downgraded. He believes that women who lose their honor claim that they still have it. In this case, women aren't to be believed because their appearances are different from their essence.

In addition, when Othello decided to kill Desdemona, he wants to poison her. Instead, Iago suggests that he should "strangle her in her bed, even the bed she hath contaminated" (4.1.195-96). One might wonder why would Iago ask Othello to strangle Desdemona. The answer is that if Desdemona was poisoned then she might die without feeling any pain. Even if Desdemona was stabbed, she might return her conscious or might be saved. But in smothering her, her breath will be cut forever so she will never be alive again. This way of murdering is actually very sever and savage. Moreover, this way of murdering portrays Iago's hate to women.

\section{The Discourse of Identity in Iago's Speech}

Iago's discourse of identity depends mainly on two facts. The first one is that Othello is black and necessarily different from the white Venetians. The second fact is that Othello is a stranger, so he must be treated as a stranger even if he tries to accommodate with the Venetian society. To be a member in a society means that you speak its language and behave like its people. Iago utilizes Othello's strange identity for his own sake to achieve his goals.

Othello, from the very begging of the play, tries to find a place in the Venetian society. When Iago warned him that Brabantio is a senator so he can harm him, Othello's reply was that:

Let him do his spite;

My services which I have done the signiory

Shall out-tongue his complaints. 'Tis yet to know -

Which, when I know that boasting is an honour, 
Othello thinks that the services he has done to the state enables him to marry a girl like Desdemona. Moreover, Othello claims that his origins are from royal siege so he isn't lower in rank or blood than Brabantio. These lines actually show how Othello was feeling that he is a stranger from Venice and that he fights to achieve a considerable status in the Venetian society. However, Othello doesn't forget that he is black and this is the reason why he married Desdemona clandestinely. He is very sure that if he asked Desdemona's hand from her father, he wouldn't agree. After he eloped with Desdemona, the need for him to defend Cyprus against the Ottomans played a great role in approving his marriage. However, after the war has stopped, the conflict appeared to the surface and the image of Othello the black, not the valiant Othello, controls the scene.

It is worth mentioning that Iago is a very clever character. He was able to read Othello's personality which helps him carry out his plans successfully. He says that "The Moor is of a free and open nature, that thinks men honest that but seem to be so" (1.3.381-382). It is true that Othello was deceived by Iago's character that he still to the last scene of the play thinks that he is honest and wise. However, Othello's naivety is being exaggerated by the playwright. That is Othello is a leader of a big army who have battles in which he won and then being deceived by his 'ensign'.

In Act three, Iago is trying to convince Othello that Desdemona has a sexual relationship with Cassio. One of Iago's means to achieve this purpose is that Othello is a stranger from Venice and has a different identity. He says:

I know our country disposition well:

In Venice they do let God see the pranks

They dare not show their husbands. Their best

Conscience. Is not to leave't undone, but keep't unknown.

\section{(3.3.203-207)}

In these lines, Iago is introducing himself to Othello as a cultural advisor. He suggests that he knows everything about the nature of his country's women which Othello doesn't know because of his strangeness. It is difficult to imagine how Othello who lived for a long period in Venice and speaks its language doesn't know its customs and culture. One reason might be behind this unawareness of the Venetian's traditions is that the playwright wants to stress the idea of Othello's strangeness.

Furthermore, Iago tries every possible mean to return Othello to his origins. In other words, Iago's success of convincing Othello is that he touches upon Othello's anxieties and fears. He tells Othello that:
Ay, there's the point: as, to be bold with you,
Not to affect many proposed matches
Of her own clime, complexion, and degree,
Whereto we see in all things nature tends. (3.3.230-233).

Iago here uses Othello's different identity perfectly to make him believe what he says. He is suggesting to Othello that his marriage isn't natural because Desdemona 
chooses him and refuses to marry her suitors from her country and who are equal to her class. As mentioned earlier, Othello feels that he is alienated from the Venetian society. Moreover, it was clear that Iago's lines above have touched his fears and discomfort. Othello expresses this feeling when he says "Haply for I am black, and have not those soft parts of conversation that chambers have, or for I am declined into the vale of years" (3.3.265-268). Gonzalez (1985) points out that Iago has infected Othello by making him over-conscious of his racial background. As a result, Othello's feeling of being alienated is reinforced.

In Act four, Iago succeeds in returning Othello to his origins and in breaking the Venetian half that Othello has. The playwright depicts Othello as a savage and violent and black people are often seen with these traits by the dominant culture in Europe. When Othello wants to take revenge from Desdemona and Cassio because they cuckold him, he says "I would have him nine years a-killing" (4.1.169). Moreover, Othello confirms that he "will chop her into messes" (4.1.188). These violent suggestions of killing by Othello confirm the traits that people already know about black people and this is what the playwright is insisting upon; to portray blacks as savage and Barbarian people.

\section{The use of Rhetorical Questions (RQs) in Iago's Speech}

Rhetorical questions are defined, according to Rohde (2006, p. 134) as "questions that neither seek information nor elicit an answer". As a result, rhetorical questions have the power of assertion and don't seek information like yes-no questions. This gives them persuasive effect. In other words, rhetorical questions provoke the listener to think about certain ideas and revise his point of view towards certain issues. That is to say that the recipient of RQs will understand that the answer to this question is too obvious to require a reply. As a result, RQs are classified as a figure of speech. Abioye (2011, p. 291) confirms that "the purpose of this figure of speech isn't to secure a response but to assert or deny a point implicitly".

In Act two, Iago tells Rodrigo that Desdemona would stop loving Othello because she will become bored of his tales. He suggests another reason why would Desdemona stop loving Othello by asking: "What delight shall she have to look on the devil?" (2.1.216). As mentioned earlier, the purpose of these rhetorical questions isn't to get an answer. The main purpose of these questions is to persuade Rodrigo that Desdemona will abandon Othello. Rodrigo, as a result, will start thinking that if Desdemona loved Othello for his tales then she will become bored, sooner or later, and leave Othello. In addition, Othello is a black person so he isn't a beautiful man and this will make Desdemona hates him as a consequence.

In Act two, scene three, Iago has succeeded in making Cassio and Montano fight each other. In the presence of Othello, Iago asks rudely "Have you forgot all place of sense and duty?" (2.3.149). Here Iago wants to show that Cassio doesn't carry out properly his duty. His intension is to make Othello start thinking of the position he gave to Cassio and that the latter doesn't deserve to be his lieutenant. By asking this rhetorical question, Othello starts thinking that Cassio doesn't deserve to be his lieutenant so he tells Cassio "I love thee, but never more be officer of mine." 
(2.3.229-30). This is the persuasive effect of Iago's use of rhetorical questions and the successful rhetorical strategy he follows to achieve his goals.

Act three is known as the 'temptation scene' in which Iago rises Othello's suspicion against his wife. The temptation process starts by Iago with a rhetorical question:

Iago: Ha! I like not that.

Othello: What dost thou say?

Iago: Nothing my lord; or if - I know not what.

Othello: Was not that Cassio parted from my wife?

Iago: Cassio, my lord? No, sure I cannot think it

That he would steal away so guilt-like,

Seeing you coming. (3.3.34-40)

Despite the fact that Iago knows it is Cassio who has already left Desdemona, he pretends in front of Othello that he doesn't know. This will make Othello think that Iago is hiding something and will start to discover this mystery. Moreover, Iago continues asking Othello provocative rhetorical questions. He asks Othello "Did Michael Cassio, when you wooed my lady, know of your love?" (3.3.93-4). In fact, Iago knows quite well that Cassio was the mediator between Othello and Desdemona. However, he aims by asking this question to make Othello pay attention to what is happening between Cassio and Desdemona. In addition, Iago goes on with his rhetorical questions:

Othello: Why of thy thought, Iago?

Iago: I did not think he had been acquainted with her.

Othello: $\mathrm{O}$ yes, and went between us very oft.

Iago: Indeed?

Othello: Indeed? Ay, indeed... is he honest?

Iago: Honest, my lord?

Othello: Honest? Ay, honest....

Othello: What dost thou think?

Iago: Think, my lord?

Othello: Think, my lord! By heaven, he echoes me. (3.3.98-109).

The purpose of this repeated use of rhetorical questions by Iago is to raise suspicion in Othello's mind. Whenever Othello says about Cassio that he is honest and good, Iago immediately asks a rhetorical question not a direct accusation as if he is surprised by Othello's idea about Cassio or to deny what Othello thinks of him. This rhetorical strategy will make Othello start looking with suspect at Cassio and incriminate him.

Furthermore, when Othello's doubts have reached their peak, he asks Iago to give him "the ocular proof" (3.3.361) that Desdemona is a whore. Iago rudely asks "Is't come to this?" (3.3.364). Iago knows very well that Othello was affected by his machinations and that Othello's jealousy starts eating him. By asking this rhetorical question, Iago wants to incite Othello and confirm that his thoughts about Cassio and Desdemona were right. A great evidence which proves this analysis is when Iago asks "Are you a man? Have you a soul? Or sense?" (3.3.373-4). By asking 
these questions, it is as if Iago makes ascertain that the relationship between Cassio and Desdemona is true and real and urges Othello to be a man and accept this fact.

Act four opens with a dialogue between Othello and Iago and starts with rhetorical questions:

\author{
Iago: Will you think so? \\ Othello: Think so, Iago? \\ Iago: What, to kiss in private? \\ Othello: An unauthorized kiss!" (4.1.1-3).
}

This suggests that there was a dialogue between Iago and Othello before the scene opens. Moreover, Iago continues his insinuations of Othello by creating images in Othello's head; images of kissing and lying in bed between Desdemona and Cassio. Iago continues his incitement of Othello by asking "Or to be naked with her friend in bed an hour or more, not meaning any harm?" (4.1.3-4). Here Iago creates sexual images of Cassio and Desdemona naked in bed without meaning any harm. It is as if Iago, by asking this rhetorical question, is evoking Othello's anger towards his wife. As a result, Othello replies sadly "Naked in bed, Iago, and not mean harm?" (4.1.5).

\title{
8. Conclusion
}

The findings of the study show that Iago's use of animal metaphors aims at dehumanizing and debasing other characters. Iago uses nineteen animal metaphors in Othello and most of them degrade other characters. Moreover, these animal metaphors are conceptualized. That is to say, Iago describes human traits in comparison with animal traits like lust, cunning and craftiness, ill-tempered, foolishness and the like. In addition, the Critical Discourse Analysis of Iago's speech in Othello shows how Iago exploits Othello's black color to achieve his goals. Iago is able to alienate Othello because of his different identity and different color from the Venetian society. Further, analyzing Iago's speech regarding gender shows his misogynistic attitudes toward women. Iago thinks that all women are like each other. That they are dishonest, foolish and inferior to men. The analysis of Iago's rhetorical speech in Othello was also revealing. Iago shows an exceptional ability in his rhetoric. He manipulates most of the characters in the play and is able to deceive all of them. Iago's use of rhetorical questions in the play is distinguished. He uses at least fifty rhetorical questions through the course of the play to persuade other characters since rhetorical questions are known for their persuasive effects. What's more, Iago has the ability to persuade other characters by playing on their emotions and feelings.

\section{References}

Abioye, T. (2011). Preference For Rhetorical Questions as an Index of Textual Message Effectiveness. International Journal of Humanities and Social Science, 1(11), 290-299.

Adelman, J. (1997). Iago's Alter Ego: Race as Projection in Othello. ShakespeareQuarterly, 48(2),125-144. 
Baecker, D. L. (1999). Tracing the History of a Metaphor: All Is Not Black and White in Othello. Comitatus: A Journal of Medieval and Renaissance Studies, 30(1).

Bate, Jonathan. (2010). Othello and the Other: Turning Turk: The subtleties of Shakespeare's treatment of Islam. The New York Times Literary Supplement, October 19, 2001. Web. 20 Dec. 2010.

Blommaert, J. (2005). Discourse: A Critical Introduction. UK. Cambridge University Press.

Bowdle, B. F., \&Gentner, D. (2005). The career of metaphor. Psychological review, 112(1), 193

Braxton, P. N. (1990). Othello: the Moor and the metaphor. South Atlantic Review, $55(4), 1-17$.

Dictionary, O. E. (2003). Oxford English Dictionary.

Egan, G. (2007). Shakespeare. Edinburgh, Edinburgh University Press Ltd.

Fairclough, N. (2012). Critical Discourse Analysis. In James, P. G \& Michael, H (Eds.), The Routledge Handbook of Discourse Analysis (pp. 9-21). London and New York, Routledge Taylor \& Francis Group.

Fontecha, A. F., \&Catalán, R. M. J. (2003). Semantic derogation in animal metaphor: a contrastive-cognitive analysis of two male/female examples in English and Spanish. Journal of pragmatics, 35(5), 771-797.

Gonzalez, A. G. (1985). The Infection and Spread of Evil: Some Major Patterns of Imagery and Language in" Othello". South Atlantic Review, 50(4), 35-49.

Hadfield, Andrew. (Ed.). (2005). William Shakespeare's Othello. London and New York: Routledge Taylor and \& Francis Group.

Konigsberg, L. (2012). A jest's prosperity lies in the ear/Of him that hears it, never in the tongue/Of him that makes it (Doctoral dissertation, The Graduate School, Stony Brook University: Stony Brook, NY.).

Lakoff, G. (1993). The Contemporary Theory of Metaphor. In Andrew, O (Ed.), Metaphor andThought ( $2^{\text {nd }}$., pp. 202- 251). UK. Cambridge University Press.

Lakoff, G., \& Johnson, M. (1980). Conceptual metaphor in everyday language. The journal of Philosophy, 77(8), 453-486.

Neill, M. (1989). Unproper Beds: Race, Adultery, and the Hideous in Othello. Shakespeare Quarterly, 40(4), 383-412.

Neill, M. (1998). " Mulattos,"" Blacks," and" Indian Moors": Othello and Early Modern Constructions of Human Difference. Shakespeare Quarterly, 49(4), 361-374.

Rand, F. P. (1950). The over garrulous Iago. Shakespeare Quarterly, 1(3), 155-161.

Reitz-Wilson, L. (2004). Race and Othello on Film. Comparative Literature and Culture, 6(1), 10.

Rohde, H. (2006). Rhetorical questions as redundant interrogatives. Department of Linguistics, UCSD.

Rose, M. S. (2008). Race and Patriarchy in Othello. The International Journal of Bahamian Studies, 11, 25-33.

Roux, D. (2009). Hybridity, Othello and the postcolonial critics. Shakespeare in southern Africa, 21(1). 
Shakespeare, W. (2003). Othello. Sander, N (Ed). UK. Cambridge University Press.

Sharma, B.(2015). Decoding Iago's Villainy through his Discourse. International journal of English language, literature and humanities. Volume III. P.P: 661672.

Silaški, N. (2014). Animal Metaphors and Semantic Derogation-Do Women Think Differently from Men?. Gender Studies, 12(1), 319-332.

Van Dijk, T. A. (2001). Critical discourse analysis. The handbook of discourse analysis, 349-371.

Vitkus, D. J. (1997). Turning Turk in Othello: The Conversion and Damnation of the Moor. Shakespeare Quarterly, 48(2), 145-176.

Wilkinson, P. R. (2004). Thesaurus of traditional English metaphors.

Wodak, R., \&Fairclough, N. (2004). Critical discourse analysis. Qualitative Research Practice: Concise Paperback Edition, 185-202.

Wodak, R., \& Meyer, M. (Eds.). (2009). Methods for critical discourse analysis. Sage Publications Ltd: London. 